\title{
Concept clarification of «delayed surgical recovery» for clinical practice implementation
}

\author{
Clarificação do conceito "recuperação cirúrgica retardada» para uso na prática clínica \\ Clarificación del concepto de «recuperación quirúrgica tardía» para usarlo en la práctica \\ clínica
}

Tallita Mello Delphino*; Rosimere Ferreira Santana**; Priscilla Alfradique de Souza***

\begin{abstract}
Context: While the concept of "delayed surgical recovery" has a high estimated occurrence in surgical nursing practice, the lack of specificity of critical attributes has interfered with diagnostic accuracy and consequent application in clinical practice. There is thus a need for concept clarification.

Objectives: To analyse of the concept of the nursing diagnosis «delayed surgical recovery», using the method of Walker and Avant, 2011.

Main topics under analysis: Critical attributes were identified and antecedents and consequences were pointed out. Model, contrary, and illegitimate cases are presented. Suture dehiscence, hyperaemia, presence of secretion in the surgical wound, prolonged postoperative time, and reporting that more time is needed for recovery were the key critical attributes for diagnosis.

Conclusion: The concept analysis made it possible to establish the boundaries of the defining attributes and provide the basis to develop the cases that explain the circumstances surrounding the diagnosis of «delayed surgical recovery».
\end{abstract}

Keywords: nursing diagnosis; perioperative nursing; concept development; nursing.

\section{Resumo}

Contexto: Embora o conceito «recuperação cirúrgica retardada» apresente uma alta estimativa de ocorrência na prática de Enfermagem cirúrgica, a inespecificidade dos atributos críticos tem interferido na acurácia diagnóstica e consequente aplicação na prática clínica. Verifica-se assim a necessidade de clarificação do conceito.

Objetivo: Analisar o conceito do diagnóstico de Enfermagem «recuperação cirúrgica retardada», através do método de Walker e Avant, 2011.

Principais tópicos em análise: Foram identificados atributos críticos e apontados antecedentes e consequentes. São apresentados casomodelo, caso-contrário e caso-ilegítimo. Deiscência da sutura, hiperemia, presença de secreção na ferida operatória, prolongamento do tempo de pós-operatório e relato de que é necessário mais tempo para recuperação mostraram-se como os principais atributos críticos para o diagnóstico.

Conclusão: A análise do conceito permitiu delimitar os atributos definidores e oferecer a base para o desenvolvimento dos casos que explicitam as circunstâncias de ocorrência do diagnóstico de «recuperação cirúrgica retardada».

Palavras-chave: diagnóstico de enfermagem; enfermagem perioperatória; formação de conceito; enfermagem.

* Post-graduation, RN, Fluminense Federal University, 24020-091, Rio de Janeiro, Brazil [tallitamell@hotmail.com]. Contribution to the article: bibliographic search; data collection, analysis and discussion; article writing. Address for correspondence: Rua Dr. Celestino, no 74 - Centro - Niterói - 24020-091, Rio de Janeiro, Brazil.

** Ph.D., RN, Medical-Surgical Department (Mem), Aurora de Afonso Costa Nursing School - Fluminense Federal University, 24020-091, Rio de Janeiro, Brazil [rosifesa@ gmail.com]. Contribution to the article: data analysis and discussion; article writing. *** MSc., RN, University of Texas Health Science Center, San Antonio, 78229, Texas, United States of America [prialfra@hotmail.com; priscillalfradique@gmail.com]. Contribution to the article: data analysis and discussion; article writing.

\section{Resumen}

Contexto: Aunque el concepto de «recuperación quirúrgica tardía» presente un índice de ocurrencia elevado en la práctica de enfermería quirúrgica, la falta de especificidad de los factores críticos ha interferido en la precisión diagnóstica y en la consecuente aplicación en la práctica clínica. Por lo tanto, es la necesidad de aclarar el concepto.

Objetivos: Analizar el concepto de diagnóstico de enfermería en la «recuperación quirúrgica tardía» a través del método de Walker y Avant, 2011.

Principales temas de análisis: Se identificaron atributos críticos y se nombraron antecedentes y consecuentes. Se presentan caso-modelo, caso-contrario y caso-ilegítimo. La dehiscencia de sutura, la hiperemia, la presencia de secreción de la herida quirúrgica, la prolongación del tiempo posoperatorio y el informe de que se necesita más tiempo para la recuperación se mostraron como los atributos más importantes para el diagnóstico.

Conclusión: El análisis del concepto permitió delimitar los atributos definidores y ofrecer la base para el desarrollo de los casos que explican las circunstancias de ocurrencia del diagnóstico de la «recuperación quirúrgica tardía».

Palabras clave: diagnóstico de enfermería; enfermería perioperatoria; formación de concepto; enfermería.

Received for publication: 05.12 .14 Accepted for publication: 23.03.15 


\section{Introduction}

The nursing diagnosis «delayed surgical recovery» was added to the NANDA-I classification in 1998, in Domain 11, Safety and Protection. It is defined as an "extension of the number of postoperative days required to initiate and perform activities that maintain life, health, and well-being" (Herdman \& Kamitsuru, 2014, p. 404).

The need to conceptually analyse a diagnosis comes from the fact that some concepts are often used mistakenly or are misunderstood by nursing professionals due to confusing terminology or how the concepts have been developed (Moreira et al., 2014). Thus, there is a need for strategies that can help develop them so that they can be clearly explained in terms of their representation of reality (Andrade, Fernandes, Nóbrega, Garcia, \& Costa, 2012; Moreira et al., 2014). Therefore, concept analysis can be defined as a method used to specify or clarify an existing concept and it has the purpose of outlining the attributes or characteristics of the phenomenon studied (Walker \& Avant, 2011).

While «delayed surgical recovery» is a diagnosis that is clearly expected in surgical nursing practice and is connected to the early detection of surgical complications, there are few studies that focus on it. After searching in the literature, it was found that nurses had difficulty identifying this diagnosis in clinical practice or identifying its defining characteristics and related factors (Lopes, Moura, Raso, Vedovato, \& Ribeiro, 2013; Pivoto, Lunardi Filho, Santos, Almeida, \& Silveira, 2010; Silva, Viana, $\&$ Volpato, 2008).

However, in a study by Santana, Amaral, Pereira, Delphino, and Cassiano (2014), estimates of the occurrence of the diagnosis of «delayed surgical recovery» were found. Upon sampling 72 individuals, including surgical adults and elderly people, the diagnosis had a prevalence of $36.67 \%$, with a relative increase in the diagnosis rate for the elderly group (77.1\%) compared to the diagnosis rate for adults (75.7\%).

This data demonstrates the importance of using this diagnosis in clinical practice and the need to clarify the occurrence of the diagnosis. In addition, it may help in the early detection and prevention of clinical findings of this diagnosis and enable the proper implementation of nursing diagnosis in clinical practice.
In order to provide qualified assistance, addressing the needs of the surgical patient, it is necessary for nursing professionals to correctly identify the nursing diagnoses in this area (Moreira et al., 2014). Accurate and precise identification of the nursing diagnosis «delayed surgical recovery» is an essential tool to promote the proper guidance for full recovery, the correct use of surgical dressing, prevention of infection, proper food and to resume routine activities. Therefore, it will help reduce postoperative complications (Meeker \& Rothrock, 2011). Considering the aforementioned, the purpose is to analyse the concept of the nursing diagnosis «delayed surgical recovery».

\section{Development}

A concept analysis of the nursing diagnosis «delayed surgical recovery» was conducted. Due to its clear theoretical-practical applicability for nursing diagnoses (Guedes \& Lopes, 2010), we chose the model proposed by Walker and Avant (2011). This model consists of eight steps: 1 - Selecting the concept; 2 - Determining the purposes of the concept analysis; 3 - Identifying the uses of the concept; 4 - Determining the critical attributes (diagnostic elements that differentiate the phenomenon); 5 - Developing the model cases; 6 - Developing other cases; 7 - Identifying the antecedents and consequences; 8 - Defining the empirical referents. After identifying the concept to be analysed, the purpose of the analysis was established: determining the critical attributes and operational definitions of the concept «delayed surgical recovery». In the third phase of the study, an integrative literature review was performed to find studies related to the topic. The search was performed on the MEDLINE databases via PubMed, LILACS (Latin American and Caribbean Literature in Health Sciences), BDENF (Nursing Database), and CINAHL (Cumulative Index to Nursing and Allied Health Literature), from January to February 2012, using the following keywords: «nursing diagnosis», «perioperative nursing» and «postoperative care» in Portuguese and in English and linked to one other. We included full articles available in English, Portuguese, and Spanish. Of a total of 222 articles, 92 full-text articles were retrieved. Of these, 54 repeated articles were retrieved and 38 selected 
articles remained. After completely reading these 38 articles, we selected nine studies that mentioned the nursing diagnosis «delayed surgical recovery».

The articles were read thoroughly and the operational definitions were identified and organised using an instrument drawn up for that purpose. The definitions were classified for each defining characteristic and each factor related to the nursing diagnosis «delayed surgical recovery», as well as for the attributes found in the literature that were not found a priori in the classification.

The later stages of identifying critical attributes, developing model cases, developing other cases, identifying antecedents and consequences and defining empirical referents will be described later on to improve understanding. The definition of each attribute was sought in order to analyse them more deeply. Definitions that were not sufficiently specific in the review were supplemented using dictionaries and/or basic literature on surgical nursing.

The study results were presented by thematic categories that were the result of the stages of the concept analysis. As the study did not make use of research involving humans, it did not need to be submitted to the Research Ethics Committee.

\section{Use of the concept}

In the integrative literature review, we identified little use of the concept «delayed surgical recovery» in the field of nursing. Commonly, we find nurses who identify patients with impaired skin integrity, impaired physical mobility, acute pain, and prolongation of hospital stay (Pivoto et al., 2010; Silva et al., 2008). However, in the literature, there are few reports relating specifically to the nursing diagnosis «delayed surgical recovery» (Appoloni, Herdman, Napoleão, Carvalho, \& Hortense, 2013; Santana et al., 2014). This does not mean that the phenomenon does not occur in clinical practice. However, it is defined mainly as postoperative complications and studies concentrate on the medical area, dehiscence care, postoperative infection prevention, respiratory complication prevention, among other aspects (Feijó, Cruz, \& Lima, 2008; Lenardt, Melo, Betiolli, Seima, \& Michel, 2010; Meeker \& Rothrock, 2011).

Based on the scientific literature, it was observed that the definition of «delayed surgical recovery» is linked to a core idea that can be defined as an increase in the number of postoperative days, difficulty in self-care and delay in wound healing. This enables a discussion on the concept for clinical practice (Feijó et al., 2008; Pivoto et al., 2010; Silva et al., 2008).

\section{Critical attributes}

Defining attributes, also called critical attributes, are characteristics that act as evidence for differential diagnosis, that is, they distinguish between what is an example of the concept and what is not. They are the elements that form the concept and define it theoretically and operationally. The set of attributes is what makes it possible to identify it when it occurs (Walker \& Avant, 2011). They are described in Table 1.

Table 1

Distribution of critical attributes and their operational definitions

\begin{tabular}{lll}
\hline $\begin{array}{l}\text { Critical attributes of } \\
\text { the concept }\end{array}$ & Operational definitions & References \\
\hline $\begin{array}{l}\text { Delays the return to work } \\
\text { and employment; }\end{array}$ & $\begin{array}{l}\text { Delayed return to usual life and work activities arising } \\
\text { from lack of full recovery. }\end{array}$ & $\begin{array}{l}\text { Feijó et al. (2008); Meeker e Ro- } \\
\text { throck (2011); Pivoto et al. (2010); } \\
\text { Silva et al. (2008); }\end{array}$ \\
Difficulty moving; & Restriction to physical movement. & $\begin{array}{l}\text { Pivoto et al. (2010); Silva et al. } \\
\text { (2008); }\end{array}$ \\
Needs help to complete & Reduced ability to carry out activities that maintain life, & Meeker e Rothrock (2011); Silva et
\end{tabular}

self-care;

Reports that more time is needed for recovery;

Suture dehiscence; bealth and well-being, such as bathing/hygiene, dressing al. (2008); and eating.

Perception that the patient has about his/her own recovery. When reporting the need for a longer period to recover Separation of fascial layers at the beginning of the postoperative period.
Pivoto et al. (2010);

Lopes et al. (2013);

Feijó et al. (2008); Lenardt et al. (2010); 
Hyperaemia in the surgical Redness in the surgical wound. wound;

Presence of secretion in the surgical wound;

Oedema in surgical wound;

Discomfort;

Extension of the postopera- Increase in number of postoperative days. tive period;

Loss of appetite;

Decreased acceptance of the diet.
Feijó et al. (2008);

Lenardt et al. (2010);

Feijó et al. (2008);

Lenardt et al. (2010);

Côrtes (2013);

Lasaponari, Costa, Peniche, e Leite (2013);

Feijó et al. (2008); Meeker e Ro-

throck (2011); Pivoto et al. (2010);

Silva et al. (2008);

Tennant et al. (2012).
Delaying the return to work and employment is the result of a process of late recovery, delaying the normal activities of life and work (Meeker \& Rothrock, 2011), as a result of failure to fully recover.

Difficulty moving can occur during surgical recovery and is characterised by restrictions to physical movement, due to the feeling of pain common in this period, orthopaedic conditions and/or the presence of drains that restrict movement of the body (Pivoto et al., 2010; Silva et al., 2008).

Often the user needs belp to complete self-care, since it is known that surgical procedures usually cause changes to the completion of self-care due to pain and fatigue, and there is difficulty bathing/completing hygiene tasks, dressing and feeding (Silva et al., 2008). The difficulty in completing self-care and the delay to returning to work and employment activities relate to a failure to fully recover and they are therefore considered to be defining characteristics (Meeker \& Rothrock, 2011; Pivoto et al., 2010; Silva et al., 2008). For perception that more time is needed for recovery, we suggest a new formulation: reports that more time is needed for recovery. This attribute refers to the perception that the patient has of his/her recovery (Lopes et al., 2013). He/she may report that he/she does not feel fully recovered and needs a few more days to achieve full recovery. The reformulation of this attribute was deemed to be important so that there would be no confusion with the factor related to postoperative expectations. In addition, it is clear that it deals with the patient's considerations about his/her recovery.

The authors define evidence of interruption in bealing of surgical area as something unexpected that happens after a surgical procedure. They indicate suture debiscence as a common complication of surgical wounds (Appoloni et al., 2013; Feijó et al., 2008; Lenardt et al., 2010; Meeker \& Rothrock, 2011).
Suture dehiscence is a great concern because it leads to prolonged recovery (Feijó et al., 2008; Lenardt et al., 2010).

It can be inferred that local redness, oedema and yellowish secretion are also often associated with the diagnosis. In other words, if the surgical wound has one of the signs described above, it can be said that the individual has «delayed surgical recovery».

Evidence of interruption of healing is considered as a generic term that can cause the nurse not to apply the diagnosis because of his/her lack of understanding. It is therefore suggested that this term be complemented by specific evidence such as oedema in the surgical wound, byperaemia in the surgical wound, presence of secretion in the surgical wound and suture dehiscence, seen when there is an interruption in healing.

According to the results found in articles, we saw that reports of fatigue and pain may be considered more as actual diagnoses than defining characteristics themselves (Lasaponari et al., 2013; Lenardt et al., 2010; Lopes et al., 2013; Pivoto et al., 2010). In other words, if the patient has fatigue during his/ her recovery, this does not necessarily mean that he/ she has «delayed surgical recovery», because it may be related to the underlying pathology, commonly cancer or heart-related, and thus the diagnosis of fatigue is presented in accordance with NANDA-I (Herdman \& Kamitsuru, 2014).

Reports of pain may be an actual diagnosis (acute pain) if they occur at the beginning of the postoperative period, which is to be expected in most surgeries (Miranda, Silva, Caetano, Souza, \& Almeida, 2011). If the pain persists, the patient may have a diagnosis of chronic pain or persistent acute pain. In this case, the constant pain can be a factor that contributes to the development of «delayed surgical recovery». 


\section{Model case}

This step is intended to illustrate the concept with an example containing the defining attributes. The case must represent a standard case, with the concept and essential attributes (Walker \& Avant, 2011). The purpose of this step is to provide a practical demonstration of the concept in a relevant context.

As a model for «delayed surgical recovery», the following case was developed: M.J.L., 67 years old, male, on D15 of the postoperative period of intestinal tract reconstruction. Obesity (BMI = 35.27) and diabetes mellitus for 25 years, states be needs more time for recovery and is concerned with work because be does not feel fully recovered; he is reporting pain and discomfort in the abdominal surgical wound, which is extensive, oedematous, reddish, and has a medium amount of serous oozing and debiscence in the lower third.

\section{Additional cases}

To assist the decision regarding the attributes that are actually important for the concept, other cases are mentioned. These cases are not legitimate examples of the concept (Walker \& Avant, 2011). They are, according to the authors: related cases (that illustrate attributes further to the essential attributes that are the focus), contrary cases (cases contrary to the model case to illustrate situations where the concept is not present), illegitimate cases (situations that do not meet the principles established for the concept; they are false situations in which the concept is not truly present), borderline cases (that illustrate the difficulty in establishing the essential elements of model case) and invented cases (that illustrate only the consistency of attributes compared with the concept). As examples of additional cases, a contrary case and an illegitimate case will be presented.

\section{Contrary case:}

B.F.S., 20 years old, female, no comorbidities, D2 of postoperative period following a total thyroidectomy, has a surgical incision of approximately $6 \mathrm{~cm}$ in the anterior region of the neck, with bealing by first intention and without signs of infection, oozing, oedema or redness, likely to be discharged tomorrow.

The contrary case presented suggests that the patient has no delay in her surgical recovery (Walker \& Avant, 2011).

\section{Illegitimate case:}

V.N.F, 49 years old, D17 of hospitalisation, with medical diagnosis of stage $D$ bladder cancer, metastatic to the hip, mentioned having pain level 9 , according to the Visual Analogue Scale (VAS) for more than eight months. The patient underwent surgery for a cystostomy, which bad healed and was functioning with clear urine. Waiting for pain control plan.

The illegitimate case demonstrates that although the patient had prolonged hospitalisation, the nursing diagnosis of "delayed surgical recovery» does not apply. The nursing diagnoses of chronic pain and risk of infection apply instead, justified by the fact that the patient has no other defining attribute that suggests a postoperative complication.

\section{Antecedents and consequences}

Antecedents are situations, events or phenomena that precede the concept in question, while consequences are what happens as a result, seen as the outcome of the concept (Walker \& Avant, 2011). In other words, antecedents may precede and/or contribute to a delay in healing of the surgical wound and consequently extend the surgical recovery time of the patient. They can be seen in Table 2 . 
Table 2

Distribution of antecedents for «delayed surgical recovery»

\begin{tabular}{ll}
\hline Antecedents & References \\
\hline Pain in surgical incision & $\begin{array}{l}\text { Lasaponari et al. (2013); Lenardt et al. (2010); Miranda et al. (2011); Pivoto et al. } \\
\text { (2010); Silva et al. (2008). }\end{array}$ \\
$\begin{array}{l}\text { Postoperative infection } \\
\text { Obesity }\end{array}$ & Cốrtes (2013). \\
$\begin{array}{l}\text { Postoperative feelings } \\
\text { (anxiety, fear, stress) }\end{array}$ & Lopes et al. (2013); Pivoto et al. (2010). \\
Old age & Côrtes (2013); Feijó et al. (2008); \\
& Lenardt et al. (2010). \\
Diabetes mellitus & Côrtes (2013); Feijó et al. (2008). \\
Nutritional deficiency & Côrtes (2013); Feijó et al. (2008). \\
Use of corticosteroids & Côrtes (2013). \\
Persistent nausea and vomiting & Tennant et al. (2012). \\
\hline
\end{tabular}

Among the related factors (antecedents), pain was presented as one of the most relevant, and may lead to postoperative complications that can extend hospitalisation. Pain relief, therefore, reduces these complications (Lasaponari et al., 2013; Lenardt et al., 2010; Miranda et al., 2011; Pivoto et al., 2010; Silva et al., 2008). Postoperative pain is one of the main factors that contribute to delays in discharge from hospital and returns to hospital after discharge (Pivoto et al., 2010). We therefore consider this to be a related factor.

Postoperative infections at incision site can occur due to several factors, such as: type of wound, the patient's health, lack of communication with the patient, failure to confirm the material's expiration date, non-compliance with the logical sequence of application of the dressing or the principles of asepsis. These factors can increase the risk of infection and compromise the process of healing and recovery of the patient's skin integrity, requiring longer stays in hospital (Appoloni et al., 2013; Feijó et al., 2008; Meeker \& Rothrock, 2011; Pivoto et al., 2010; Silva et al., 2008).

Obesity, despite being found in only one article, is considered to be a risk factor due to low irrigation at the site of adipose tissue. Therefore, decreased blood flow may cause a delay in healing (Côrtes, 2013).

Similarly, postoperative expectation, according to some authors (Lopes et al., 2013; Pivoto et al., 2010), corresponds to the feelings shown that may contribute to a delay in recovery (anxiety, fear, concern, change in self-esteem). For this reason, the use of postoperative feelings is suggested to increase the clarity of its definition. It should be noted that stress, anxiety and fear cause catecholamines to be released, which may lead to increased cortisol and consequent muscle and protein exhaustion, thereby extending the healing time of the surgical wound (Lopes et al., 2013).

Old age can also contribute to a delay in recovery due to the physiological changes of ageing and chronic diseases (Côrtes, 2013; Meeker \& Rothrock, 2011). Diabetes mellitus was the most cited in the literature due to the possibility of vascular and neuropathic complications and inhibitory effects on defence mechanisms, which can lead to changes in the pathophysiology of healing (Côrtes, 2013; Meeker \& Rothrock, 2011;). Nutritional deficiency, the presence of oedema and the use of corticosteroids can also decrease immunity and act as a barrier to angiogenesis (Côrtes, 2013; Lenardt et al., 2010; Meeker \& Rothrock, 2011).

Similarly, nausea and vomiting lead to consequences such as a delay in the return to normal functions. In addition, patients who do not show improvements in related symptoms may have their discharge from hospital delayed, and may need hospitalisation after outpatient procedures.

In the diagnosis, the critical attributes will constitute the defining characteristics, just as the antecedents will be the related factors. In the proposed model, the consequences, taken as expected results, are not normally used in the diagnosis. However, they are of great help in directing the research (Walker \& Avant, 2011), and have correlations with studies of nursing outcomes (Johnson, Maas, \& Moorhead, 2004). Such 
phenomena are relevant to the nursing diagnosis «delayed surgical recovery». In Table 3, we have the main consequences identified in accordance with the concept analysis.

Table 3

Distribution of consequences for «delayed surgical recovery»

\begin{tabular}{|c|c|}
\hline Consequences & References \\
\hline Desire to eat and food intake changed; & Johnson et al. (2004); Tennant et al. (2012). \\
\hline $\begin{array}{l}\text { Impaired self-care for feeding, clothing, completing intimate bygiene, bath- } \\
\text { ing and positioning; }\end{array}$ & Johnson et al. (2004); Silva et al. (2008). \\
\hline $\begin{array}{l}\text { Impaired walking, impaired performance in transfer, movements per- } \\
\text { formed with difficulty, impaired balance; }\end{array}$ & $\begin{array}{l}\text { Johnson et al. (2004); Pivoto et al. (2010); Silva } \\
\text { et al. (2008). }\end{array}$ \\
\hline $\begin{array}{l}\text { Impaired healing by first intention (wound edges do not get closer to } \\
\text { one another; extensive purulent, serous, or blood drainage; extensive } \\
\text { erythema in skin around wound; extensive oedema around the wound; } \\
\text { unpleasant smell in the wound); }\end{array}$ & $\begin{array}{l}\text { Johnson et al. (2004); Lenardt et al. (2010); Silva } \\
\text { et al. (2008). }\end{array}$ \\
\hline Severe colonisation at injury site, severe purulent secretion; & $\begin{array}{l}\text { Johnson et al. (2004); Lenardt et al. (2010); Silva } \\
\text { et al. (2008). }\end{array}$ \\
\hline Severe level of anxiety, stress, discomfort. & Johnson et al. (2004); Lasaponari et al. (2013). \\
\hline
\end{tabular}

\section{Empirical referents}

The last phase seeks to identify empirical referents for defining attributes, categories of observable phenomena that show the occurrence of the concept (Walker \& Avant, 2011). Some existing instruments are found in the literature to measure the phenomenon of «delayed surgical recovery», such as, for example, the post-discharge surgical recovery assessment scale (Berg, Idvall, Nilsson, Arestedt, \& Unosson, 2010) and also the patient self-report questionnaire to measure postoperative recovery (Allvin, Ehnfors, Rawal, Svensson, \& Idvall, 2009), both of which are quite widespread.

In addition, there are other applicable referents, such as assessment scales and laboratory tests, that may aid in the identification of defining attributes for diagnosis, such as, for example, leukocyte counts to assess the presence of infection (Meeker \& Rothrock, 2011); the visual analogue scale (VAS) for pain assessment (Miranda et al., 2011); or Lawton and Brody's scale (Lenardt et al., 2010) for the evaluation of the autonomy of the elderly on instrumental activities of daily living.

\section{Diagnosis proposal}

In accordance with the concept analysis, the conditions of the surgical wound are extremely important in identifying the nursing diagnosis «delayed surgical recovery». It is evident that the concept of «delayed surgical recovery» can be connected to the central idea of an increase in the number of days of postoperative period, difficulty in completing self-care and a delay in wound healing.

A new definition has been proposed for the diagnosis, which facilitates identification in clinical practice: Extension of the number of days of the postoperative period required to complete healing of the wound and initiate and perform activities that maintain life, health, and well-being rather than just extending the number of days of postoperative period required to initiate and perform activities that maintain life, bealth, and well-being. In accordance with the concept analysis, there was no need to change the title of the diagnosis.

Some researchers have cited factors that could influence the healing of the surgical wound; however, they are not described in the NANDA-I classification as Related Factors of the diagnosis of «delayed surgical recovery» (Côrtes, 2013; Lenardt et al., 2010; Tennant et al., 2012). Thus, six related factors were added: old age, diabetes mellitus, nutritional deficiency, oedema, use of corticosteroids, and nausea and vomiting (Table 4). 
Table 4

Proposal for a reformulation of diagnosis for «delayed surgical recovery»

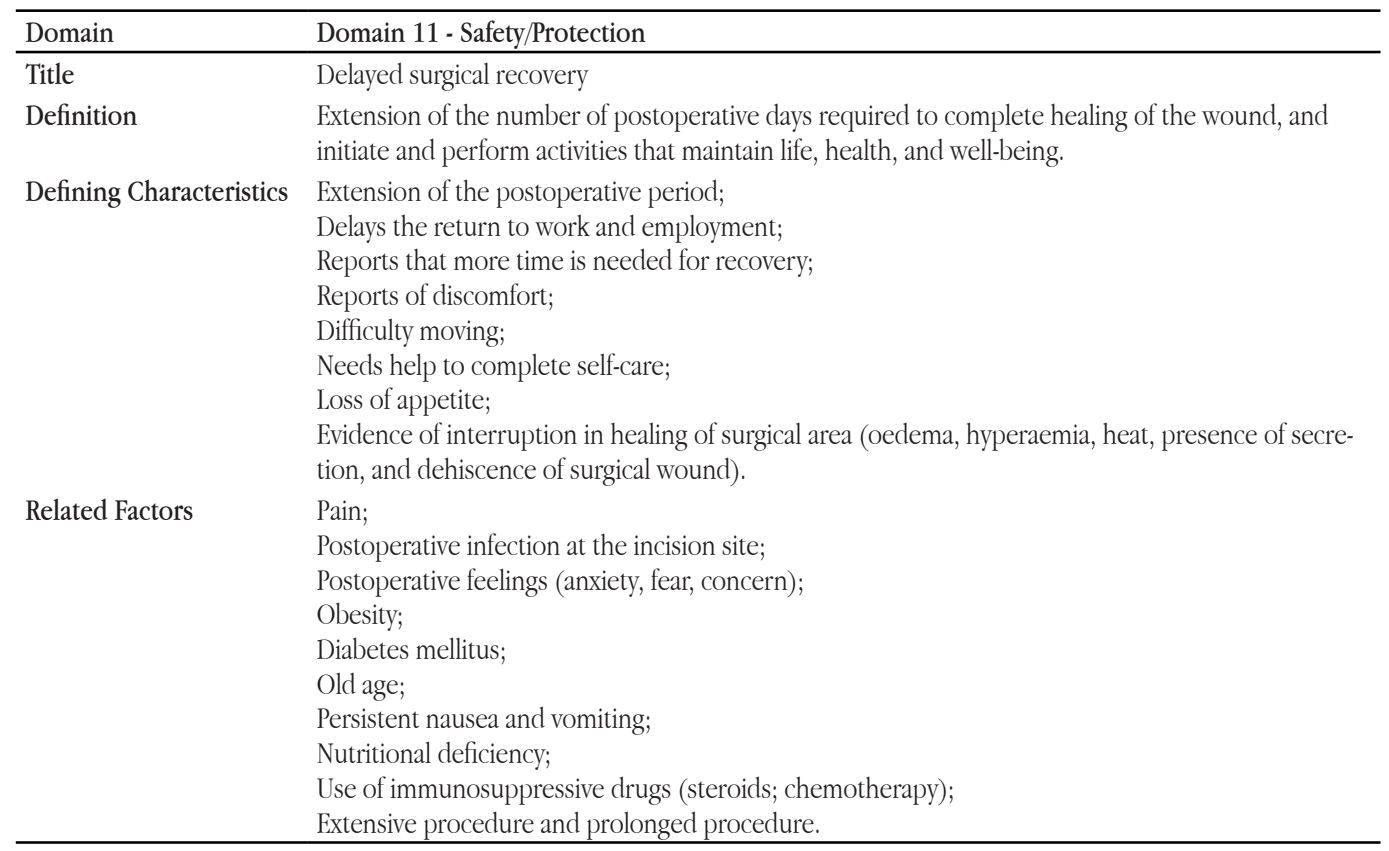

\section{Conclusion}

The concept analysis performed showed limitations as regards the lack of clear explanations of this concept in the literature. Paradoxically, extensive literature was found addressing postoperative complications, but it used medical language as the main focus.

The attributes of the diagnosis, which are the defining characteristics (extension of the postoperative period, reports that more time is needed for recovery, wound dehiscence, hyperaemia, oedema and wound secretion) and the antecedents, which are the related factors (pain, postoperative expectations, postoperative infection at the wound site and obesity) of the diagnosis of "delayed surgical recovery», were highlighted with strong clinical evidence that contributed to the development of the diagnosis.

The relevance of this study is in the proposal of operational definitions for defining attributes, which helps nurses' understanding and consequently improves nursing care. In addition, the cases enable the concept to be accurately identified in nurses' clinical practice, since they often have difficulty in determining the correct diagnosis.

The development of studies for clinical and content validation in different cultures and assistance sectors are recommended to increase the representativeness of the concept of «delayed surgical recovery».

\section{References}

Allvin, R., Ehnfors, M., Rawal, N., Svensson, E., \& Idvall, E. (2009). Development of a questionnaire to measure patientreported postoperative recovery: Contentvalidityand intra-patient reliability. Journal of evaluation in clinical practice, 15(3), 411-419.

Andrade, A. N., Fernandes, M. G., Nóbrega, M. M., Garcia, T. R., \& Costa, K. N. (2012). Análise do conceito fragilidade em idosos. Revista Texto \& Contexto Enfermagem, 21(4), 748756.

Appoloni, A. H., Herdman, T. H., Napoleão, A. A., Carvalho, E. C., \& Hortense, P. (2013). Concept analysis and validation of DSR. International Journal of Nursing Knowledge, NANDA International, 24(3), 115-121.

Berg, K., Idvall, E., Nilsson, U., Årestedt, K. F., \& Unosson, M. (2010).Psychometric evaluation of the post-discharge surgical recovery scale. Journal of evaluation in clinical practice, 16(4), 794-801.

Côrtes, S. M. (2013). Wound Treatment: A revision article. Revista de Divulgação Científica Sena Aires, 1, 55-64. 
Feijó, E., Cruz, I. C., \& Lima, D. V. (2008). Wound infection: Systematic literature review. Online Brazilian Journal of Nursing, 7(3). Retrieved from http://dx.doi.org/10.1590/ S0103- 21002011000200019

Guedes N .G., \& Lopes, M. V. (2010). Exercício físico em portadores de hipertensão arterial: Uma análise conceitual. Revista Gaúcha de Enfermagem, 31(2), 367-374.

Herdman T. H., \& Kamitsuru, S. (2014). NANDA international nursing diagnoses: Definitions \& classification: 2015-2017. Oxford, England: Wiley Blackwell.

Johnson, M., Maas, M., \& Moorhead, S. (2004).Classificação dos resultados de enfermagem (NOC) ( $2^{\mathrm{a}} \mathrm{Ed}$.). Porto Alegre, Brasil: Artmed.

Pivoto, F. L., Lunardi Filho, W. D., Santos, S. S., Almeida, M. A., \& Silveira., R. S. (2010). Nursing diagnoses in patients in the postoperative period of cardiac surgery. Acta Paulista de Enfermagem, 23(5), 665-670.

Lasaponari, E. F., Costa, A. L., Peniche, A. C., \& Leite, R. C. (2013). Revisão integrativa: Dor aguda e intervenções de enfermagem no pós-operatório imediato. Revista da Associação Brasileira de Enfermeiros de Centro Cirúrgico, Recuperação Anestésica e Centro de Material e Esterilização (SOBECC), 18(3), 38-48.

Lenardt, M. H., Melo, D. K., Betiolli, S. E., Seima, M. D., \& Michel, T. (2010). Geriatric nursing care concepts related to postoperative complications in the elderly. Cogitare Enfermagem, 15(3), 420-426.

Lopes, M. H., Moura, A. A., Raso, S., Vedovato, T. G., \& Ribeiro, M. A. (2013).

Diagnósticos de enfermagem no pós-operatório de mastectomia. Escola Anna Nery [online], 17(2), 354-360.
Meeker, M.H., \& Rothrock, J. C. (2011). Alexander's care of the patient in surgery. Mosby-Year Book.

Miranda, A. F., Silva, L. F., Caetano, J. A., Sousa, A. C., \& Almeida, P. C. (2011).

Avaliação da intensidade de dor e sinais vitais no pós-operatório de cirurgia cardíaca. Revista da Escola de Enfermagem da USP, 45(2), 327-333.

Moreira, R. P., Araujo, T. L., Cavalcante, T. F., Guedes, N. G., Lopes, M. V., \& Chaves, E. S. (2014). Análise de conceito do resultado de enfermagem Mobilidade em pacientes com acidente vascular cerebral. Revista Brasileira de Enfermagem, 67(3), 443-449.

Santana, R. F., Amaral, D. M., Pereira, S. K., Delphino, T. M., \& Cassiano, K. M. (2014). Ocorrência do diagnóstico de enfermagem de recuperação cirúrgica retardada entre adultos e idosos. Acta Paulista de Enfermagem [online], $27(1), 35-39$.

Silva, F.S., Viana, M.F., \& Volpato, M. P. (2008). Diagnósticos de enfermagem em pacientes internados pela clínica ortopédica em unidade médico-cirúrgica. Revista Gaúcha de Enfermagem, 29(4), 565-572.

Tennant, I., Augier, R., Ferron-Boothe, A. D., Meeks-Aitken, N., Jones, K., Gordon-Strachan, G., \& Harding-Goldson, H. (2012). Postoperative complications related to minors anesthesia in patients for elective surgeries gynecological orthopedic and in a University Hospital in Kingston, Jamaica. Revista Brasileira de Anestesiologia, 62(2).

Walker L. O., \& Avant. K. C. (2011). Strategies for theory construction in mursing (5th ed.). Upper Saddle River, USA: Pearson Prentice Hall. 
